\title{
THE RELATIONSHIP BETWEEN MINERAL NITROGEN CONTENT AND SOIL PH IN GRASSLAND AND FODDER CROP SOILS
}

\author{
WATROS, A. ${ }^{1}$ - LIPIŃSKA, H. ${ }^{2}$ - LIPIŃSKI, W. ${ }^{3}$ - TKACZYK, P. ${ }^{4}-$ KRZYSZCZAK, J. ${ }^{5 *}$ \\ BARANOWSKI, P. ${ }^{5}-$ BRODOWSKA, M. S. ${ }^{4}-$ JACKOWSKA, I. $^{6}$ \\ ${ }^{1}$ New Chemical Synthesis Institute \\ Al. Tysiaclecia Państwa Polskiego 13 A, 24-110 Puławy, Poland \\ ${ }^{2}$ Department of Grassland Science and Landscaping, University of Life Sciences in Lublin \\ ul. Akademicka 15, 20-950 Lublin, Poland \\ ${ }^{3}$ State School of Higher Education in Chetm, ul. Pocztowa 54, 22-100 Chetm, Poland \\ ${ }^{4}$ Department of Agricultural and Environmental Chemistry, University of Life Sciences in \\ Lublin, ul. Akademicka 15, 20-950 Lublin, Poland \\ ${ }^{5}$ Institute of Agrophysics Polish Academy of Sciences \\ ul. Doświadczalna 4, 20-290 Lublin, Poland \\ (phone: +48 (81) 74450 61; fax: +48 (81) 74450 67) \\ ${ }^{6}$ Department of Chemistry, University of Life Sciences in Lublin \\ ul. Akademicka 15, 20-950 Lublin, Poland \\ *Corresponding author \\ e-mail: jkrzyszczak@ipan.lublin.pl; phone: (81) 74450 61; fax: (81) 7445067
}

(Received $4^{\text {th }}$ Sep 2018; accepted $28^{\text {th }}$ Nov 2018)

\begin{abstract}
This study attempted to evaluate the relationship between mineral nitrogen $\left(\mathrm{N}_{\min }\right)$ content and soil $\mathrm{pH}$ in the $60-90 \mathrm{~cm}$ layer of grassland soils relative to other selected agricultural fodder crops. The area of the study uniformly covered the whole territory of Poland. The dependence between $\mathrm{N}_{\text {min }}$ content and soil $\mathrm{pH}$ was expressed as correlation coefficients, while their significance was evaluated using the one-way non-orthogonal analysis of variance classification. Regardless of sampling date (spring or autumn) and land use (meadow, pasture, hay and pasture or alternate), soil $\mathrm{pH}$ had a significant effect on $\mathrm{N}_{\min }$ concentration. The correlation between $\mathrm{N}_{\min }$ and soil $\mathrm{pH}$ in grasslands on mineral soils was positive, regardless of soil sampling date. In turn, in organic soils a negative correlation between $\mathrm{pH}$ and $\mathrm{N}_{\min }$ content was observed in the spring period, whereas in autumn this trend did not persist and the correlation was positive. On the other hand, in the case of agricultural fodder crops (maize or mixed cereal) $\mathbf{N}_{\min }$ content in the $60-90 \mathrm{~cm}$ layer and soil $\mathrm{pH}$ were found to be positively correlated, regardless of spring or autumn sampling date, with a correlation coefficient higher than 0.9. The obtained results can be used for diminishing environmental hazards.
\end{abstract}

Keywords: mineral soils, organic soils, maize, mixed cereals, regression equations

\section{Introduction}

One of the major problems related to agricultural production effectiveness is to control soil acidification through properly conducted liming treatments. Arable soils in Poland are characterized by excessive acidification, which results not only from environmental reasons, but to a large extent from incompetent land use and insufficient use of calcium fertilizers (Filipek and Skowrońska, 2013). The most commonly used 
nitrogen fertilizers causing soil acidity increase are ammonium sulphate and urea. Acidified soil prevents proper growth and development of crop plants and due to this yields obtained are much lower than potential ones (Siebielec et al., 2012; Tkaczyk and Bednarek, 2011). Improper identification of this problem can result in application of increased rates of mineral and organic fertilizers and this, in turn, has a very negative environmental impact. It leads not only to degradation of surface and groundwaters, but also to increased greenhouse gas emissions, both as a result of land use intensification and directly due to unfavorable soil $\mathrm{pH}$. However, in the context of sustainable farming a farmer should take into consideration not only the short-term impact of agricultural practices used to increase profit, but also the long-term effect associated with climate change and soil degradation. Only such an approach can lead to the maintenance of farming profitability over the long term, both at the farm level and at the level of the entire region or country, while simultaneously providing environmental protection. It is also important that the soil content of mineral nitrogen (and other macro- and micronutrients) depends, among others, on soil physical and chemical properties, among which $\mathrm{pH}$ is one of the more important factors that modify the rate of conversion of this element (Burton and Prosser, 2001; De Boer and Kowalchuk, 2001; Skowron, 2004; Coyne and Frye, 2005). Low soil $\mathrm{pH}$ promotes the process of ammonification, while at higher $\mathrm{pH}$ the process of nitrification occurs more easily (Sapek, 1999; Kyveryga et al., 2004). With a decrease in soil $\mathrm{pH}$, an increase in the ammonium nitrogen content was noted (with its maximum value at a $\mathrm{pH}$ of 3.5), but at the same time a significant decrease in the nitrate nitrogen content. The content of the nitrate form of mineral nitrogen was found to be several times lower in soils with a $\mathrm{pH}$ close to 3.5 than in soils characterized by a pH of 7.5 (Skowron, 2004). Due to this, in acidic soils one should expect lower nitrate nitrogen losses caused by leaching, but at the same time worse supply of plants with this nutrient. Proper fertilizer management, which takes into account soil acidification, is possible by using precise agriculture systems that allow the spatial variation of soil physico-chemical properties and the relationships between these properties to be taken account of. Precise agriculture systems are based on both monitoring and environmental research regarding, among others, the effects of soil physical and chemical properties on macro- and micronutrient content in various ecosystems (Tkaczyk et al., 2017; 2018a; 2018b). Such research also allows to make an assessment of the effectiveness of treatments applied by using physical and mathematical models that describe the processes occurring in the soil-plant-atmosphere system (Walczak et al., 1997; Lamorski et al., 2013). Thanks to it, a farmer knows not only what treatments should be carried out in the field and when, but he can also forecast yields and ultimately - estimate profit. The change in local climate conditions due to global climate change is one of the yield-affecting factors that are more difficult to evaluate. Therefore, in this context studies on the impact of climate change on plant production which take into account various climate change scenarios (Pirttioja et al., 2015; Fronzek et al., 2018), coupled with analysis of the effects of adaptation treatments (Ruiz-Ramos et al., 2018; Rodríguez et al., 2018), become extremely important. Soil biological activity (Wnuk et al., 2017; Gleń-Karolczyk et al., 2018; Walkiewicz et al., 2018) and atmospheric conditions should also be included in the factors that determine the direction and rate of soil nitrogen conversion. Thanks to studies on the temporal and spatial variation of meteorological series from various climatic zones (Baranowski et al., 2015; Hoffmann et al., 2017; Krzyszczak et al., 2017a; 2017b; Krzyszczak et al., 2018) and their prediction using statistical methods (Murat et al., 2018), not only can 
the impact of climate change on agricultural production be evaluated, but we can also attempt to assess this impact on the soil content of macronutrients (nitrogen).

Changes in the structure of precipitation, both its frequency and intensity, are observed as a result of climate change, which can strongly affect infiltration of mineral nitrogen contained in the soil water solution (Powlson, 1988; Trehan, 1996; Tremblay et al., 2001; Coyne and Frye, 2005) from the subsurface layer deeper into the soil profile. Some studies show that almost half of the mineral nitrogen contained in the $0-30 \mathrm{~cm}$ layer can migrate to the deeper layers due to leaching (Soon et al., 2001). Soil nitrogen leaching and penetration into groundwater are an unfavorable phenomenon ( $\mathrm{Paz}$ and Ramos, 2004) having significant economic, production and environmental consequences (Soon et al., 2001). Monitoring of soil mineral nitrogen has been conducted in Poland for many years (Lipiński, 2010; Fotyma et al., 2010; Regulation, 2002). This study attempted to identify the effects of factors such soil $\mathrm{pH}$ and land use on the content of nitrogen in the $60-90 \mathrm{~cm}$ soil layer, from which it can migrate to waters. Because soil mineral nitrogen content exhibits high temporal variability (Yu et al., 2003), with its maximum content in the soil during the spring period and the minimum content at the turn of August and September, which is a result of changes in the intensity of nitrification and enhanced nitrogen uptake by plants (Loginow et al., 1987), therefore the analysis was carried out for two sampling dates - spring and autumn. The study hypothesized that there would differences in the mineral nitrogen content beyond the reach of the main root system of crop plants in grassland and arable soils depending on selected soil properties and land use. The aim of this study was to evaluate mineral nitrogen content in grassland soils relative to other selected agricultural fodder crops depending on soil $\mathrm{pH}$.

\section{Material and methods}

\section{Soil samples analysis}

To evaluate soil mineral nitrogen content, soil samples were used which had been collected during environmental investigations conducted by the Regional Chemical and Agricultural Stations in agricultural farms across Poland. Soil samples were taken from $60-90 \mathrm{~cm}$ layer using Egner stick of the length of $90 \mathrm{~cm}$, from fields with a total area of not more than 4 ha. Each total sample (with a weight of about $200 \mathrm{~g}$ ) consisted of 15-20 primary samples collected from an area of not more than $100 \mathrm{~m}^{2}$. Samples were collected over the period 2010-2012 at two sampling dates - spring and autumn. Soil sampling in spring were conducted before applying fertilizers in February-April, whereas for sampling in autumn - after harvesting in September-October.

The collected samples were transferred to the Laboratory in tightly sealed containers and they were kept at a constant controlled temperature of $-18^{\circ} \mathrm{C}$ until the mineral nitrogen analysis was performed. The soil samples with natural moisture content (after defrosting) were subjected to extraction with a $1 \%$ potassium sulfate solution at a ratio of $1: 10$. In the extracts obtained, nitrate and ammonium nitrogen content was determined spectrophotometrically using a Skalar San Plus System auto-analyzer (according to the standard PN-R-04028:1997). Mineral nitrogen content, as total nitrate and ammonium nitrogen, was expressed in $\mathrm{mg} \cdot \mathrm{kg}^{-1}$ of dry matter of the soil sample (DM). The following parameters were also determined in the examined samples: dry matter content, soil organic carbon $\left(\mathrm{C}_{\text {org }}\right)$ using the Tiurin method (according to PN-ISO 14235:2003), grain-size distribution using the laser method, and $\mathrm{pH}$ in $1 \mathrm{~mol} \mathrm{KCl} \mathrm{dm}^{-3}$. 
Determination of dry matter was made using the gravimetric method after drying at $105^{\circ} \mathrm{C}$ (according to PN-ISO 11465:1999). As the extraction of nitrate and ammonium is carried out in a fresh soil sample, obtained results are recalculated to the dry matter content using the empirical coefficient suitable for the soil of specific granulometric composition. Based on the analysis of organic matter and $\mathrm{pH}$, soils were classified as mineral (up to 10\%) or organic (over 10\%) and were assigned to one of the following five soil pH classes (Pokojska, 2004; Gonet et al., 2015): very acidic soils ( $\mathrm{pH}<4.5$ ), acidic soils ( $\mathrm{pH}$ in the range between 4.6 and 5.5), slightly acidic soils $(5.6<\mathrm{pH}<6.5)$, neutral soils $(6.6<\mathrm{pH}<7.2)$, and alkaline soils $(\mathrm{pH}>7.2)$.

\section{Sampling sites}

Because in the first year the geographical coordinates of the sampling sites were determined, in the next years soil sampling was carried out in the same fields. Determination of geographical coordinates of sampling sites was performed using GPS Pathfinder ProXT by Trimble (Westminster, CO 80021, USA, www.trimble.com). To verify the study hypothesis, the mineral nitrogen content and soil $\mathrm{pH}$ in the $60-90 \mathrm{~cm}$ layer sampled from soils under grasslands, maize and mixed cereal crops was evaluated (Table 1). The location of soil sampling sites is shown in Fig. 1. In the case of each site where the same crop was grown in successive years of the study, the average nitrogen content for the respective years was calculated. As far as sites located in grasslands are concerned, the same land use was continued throughout the entire study period and the average $\mathrm{N}_{\min }$ content was evaluated for the period 2010-2012.
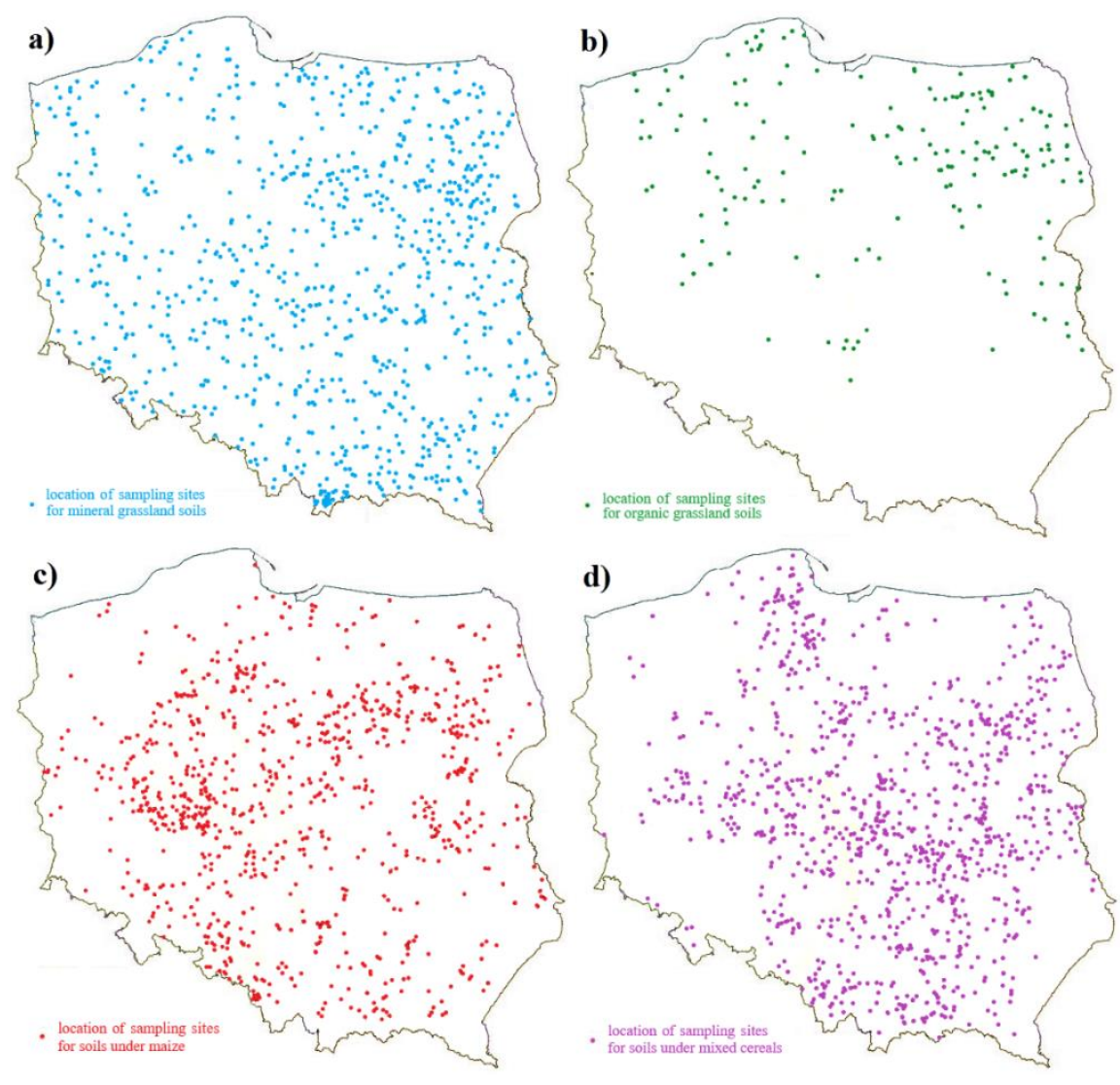

Figure 1. Location of soil sampling sites for a) grasslands on mineral soils; b) grasslands on organic soils; (c) maize; d) mixed cereals; in hydrographic areas of Poland 
Table 1. Number of analyzed soil samples taken from the 60-90 cm soil layer in grasslands as well as in maize and mixed cereal crops on mineral and organic soils

\begin{tabular}{|c|c|c|}
\hline \multicolumn{2}{|c|}{ Crop type/land use } & Number of samples \\
\hline \multirow{5}{*}{ Grasslands on mineral soils } & Total & 859 \\
\hline & Meadows & 521 \\
\hline & Pastures & 160 \\
\hline & Hay and pasture & 84 \\
\hline & Alternate & 98 \\
\hline \multirow{5}{*}{ Grasslands on organic soils } & Total & 167 \\
\hline & Meadows & 111 \\
\hline & Pastures & 17 \\
\hline & Hay and pasture & 39 \\
\hline & Alternate & 0 \\
\hline \multicolumn{2}{|c|}{ Maize } & 826 \\
\hline \multicolumn{2}{|c|}{ Mixed cereal } & 951 \\
\hline
\end{tabular}

\section{Statistical analysis}

The mineral nitrogen content in the $60-90 \mathrm{~cm}$ layer under the soil surface was evaluated both as an annual average and separately for the spring and autumn dates, depending on the determined $\mathrm{pH}$ class and land use. The study results were analyzed using standard statistical methods. By assigning the selected sites to the specific factors, such as type of land use and acidification class, basic descriptive statistics - average value and standard deviations (SD) of mineral nitrogen content were calculated. Relationships between $\mathrm{N}_{\min }$ content and a specific factor were characterized by Pearson's correlation coefficients. They were assessed statistically using the one-way non-orthogonal analysis of variance classification with Tukey confidence intervals $(\mathrm{p}=$ 0.05). In order to predict potential losses, simple regression analysis was performed in the SAS v. 9.1 software and the linear regression coefficients calculated. Obtained linear equations describe the relationship between the soil $\mathrm{pH}$ and the $\mathrm{N}_{\min }$ content in the $60-90 \mathrm{~cm}$ soil layer for varying land use and the type of soil (mineral, organic). The goodness of fit of linear regression was evaluated using determination coefficients $\left(\mathrm{R}^{2}\right)$.

\section{Results and discussion}

Mineral nitrogen content in the $60-90 \mathrm{~cm}$ soil layer was investigated taking into account the $\mathrm{pH}$ of mineral and organic soils. Regardless of the percentage of organic matter or land use, the amount of $\mathrm{N}_{\min }$ in the evaluated layer was dependent on $\mathrm{pH}$ (Fig. 2). Increase of $\mathrm{pH}$ leads to changes in resource availability for microbes and alter their community structure, modifying their activity and C-use efficiency (Kennedy et al., 2004; Grover et al., 2017). It was stated by Rousk et al. (2010) that the relative abundance and diversity of bacteria were positively related to $\mathrm{pH}$. This effect impacts mineralisation process, leading to higher $\mathrm{N}_{\min }$ content in soils with higher $\mathrm{pH}$. In our case higher $\mathrm{N}_{\min }$ content was detected in soils with a $\mathrm{pH}$ ranging 5.6-6.5, whereas its least amount in soils showing the highest acidification ( $\mathrm{pH}$ below 4.5). A similar correlation was also found in the studies of Sapek and Kalińska $(2004 ; 2007)$ and Sapek (2010). In their opinion, lower acidity reduces the release of the ammonium form of nitrogen and at the same time promotes nitrification and the release of the nitrate form of nitrogen. 


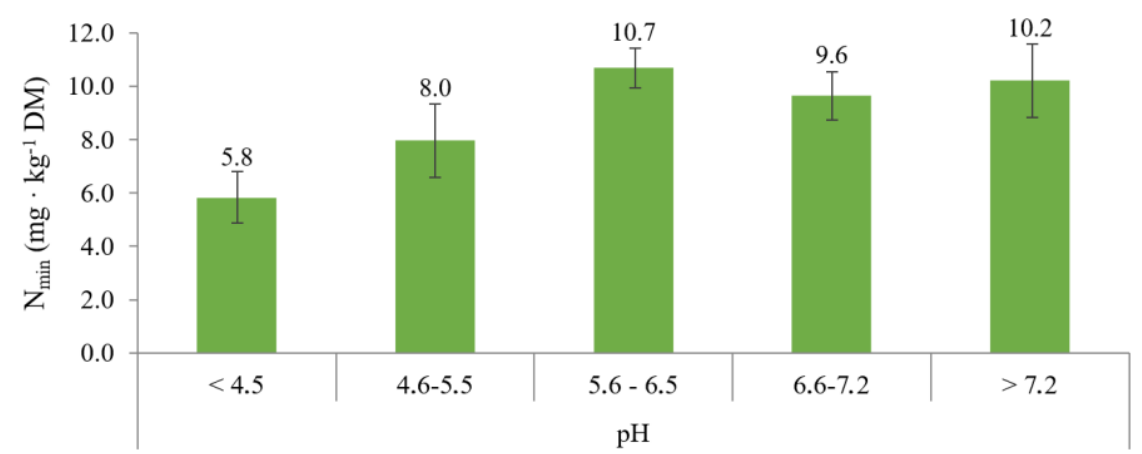

Figure 2. Average mineral nitrogen $N_{\min }$ content in the $60-90 \mathrm{~cm}$ soil layer depending on soil pH. DM stands for dry matter of the soil sample

In the present study, the amount of $\mathrm{N}_{\min }$ clearly increased with increasing $\mathrm{pH}$ of mineral soils, regardless of crops grown, whereas in organic soils the largest amounts of $\mathrm{N}_{\min }$ were found in soil with a slightly acidic $\mathrm{pH}$, followed by very acidic and acidic soils (Fig. 3). In soils with a pH above 6.5, the amount of $\mathrm{N}_{\min }$ in the $60-90 \mathrm{~cm}$ layer decreased. In organic soils significantly larger values of $N_{\min }$ content in the $60-90 \mathrm{~cm}$ soil layer were observed, regardless of the land use or soil $\mathrm{pH}$. Mineral nitrogen concentration in a specific soil layer reflects the balance of nitrogen on the one hand supplied with mineral and organic fertilisers, as well as released by microorganisms during mineralisation of organic matter, and on the other hand assimilated by plants, leached, denitrified or immobilised (Wong and Nortcliff, 1995). Recent study by Tian et al. (2017) shows that that both $\mathrm{C}$ and $\mathrm{N}$ mineralization rates in subsoil are significantly lower than in topsoil and that that net $\mathrm{N}$ mineralization in subsoil was limited by low amounts of labile $\mathrm{C}$ source (which provides energy) and degradable organic $\mathrm{N}$ (which provides material). Therefore, in mineral soils mineralization may be weaker than in organic soils due to limited $\mathrm{C}$ content, subsequently leading to significantly lower $\mathrm{N}_{\min }$ content in these soils.
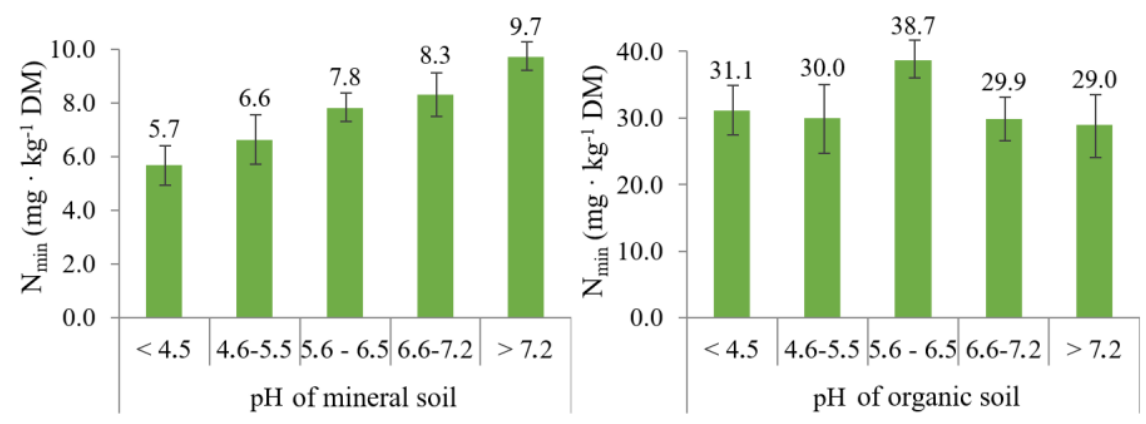

Figure 3. Average mineral nitrogen $N_{\min }$ content in the 60-90 $\mathrm{cm}$ layer of mineral and organic soils depending on soil pH. DM stands for dry matter of the soil sample

Generally, the mineral nitrogen content for the specific $\mathrm{pH}$ ranges was higher in spring, except for sites with a $\mathrm{pH}$ above 7.2 (Fig. 4). This applied to both mineral and organic soils, though as regards the latter ones with a neutral $\mathrm{pH}$, a higher content was also found for the autumn sampling date. In the study of Arbačiauskas et al. (2014) for 
Lithuanian agricultural lands the similar tendency was observed for 60-90 cm layer, regardless of different texture of subjected soils or nitrogen fertilisation rates.

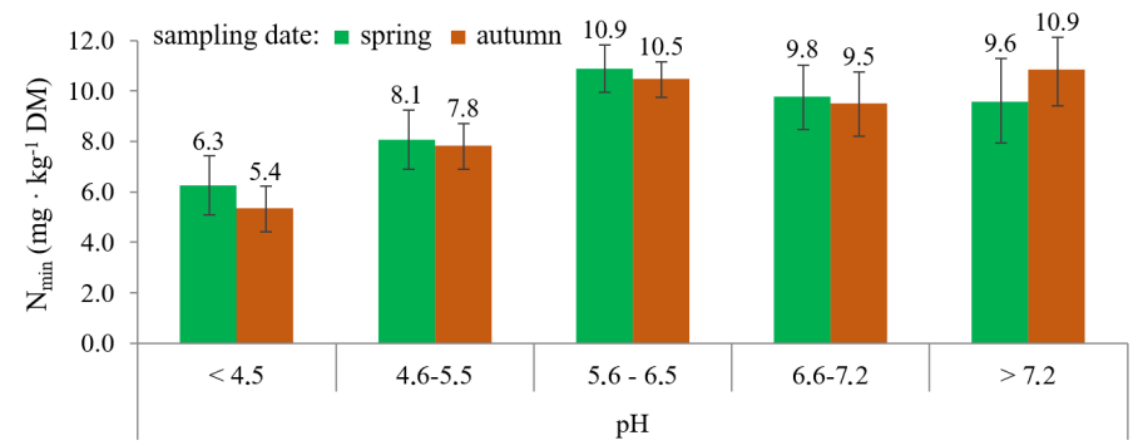

Figure 4. Average mineral nitrogen $N_{\min }$ content in the 60-90 cm layer depending on sampling date and soil pH. DM stands for dry matter of the soil sample

The highest mineral nitrogen losses as influenced by $\mathrm{pH}$ in mineral soils - as regards its content in the $60-90 \mathrm{~cm}$ layer - were observed in soils under maize crops, while slightly lower ones in soils under mixed cereals. In grasslands, this influence was clearly weaker (Fig. 5). Pietrzak et al. (2006) also demonstrated the effect of soil pH on mineral nitrogen leaching in permanent grasslands. They observed the concentration of the ammonium form to be higher by about 1.8 times and the concentration of the nitrate form by about 2.5 times in the soil solutions from limed fields compared to soil extracts from unlimed fields.

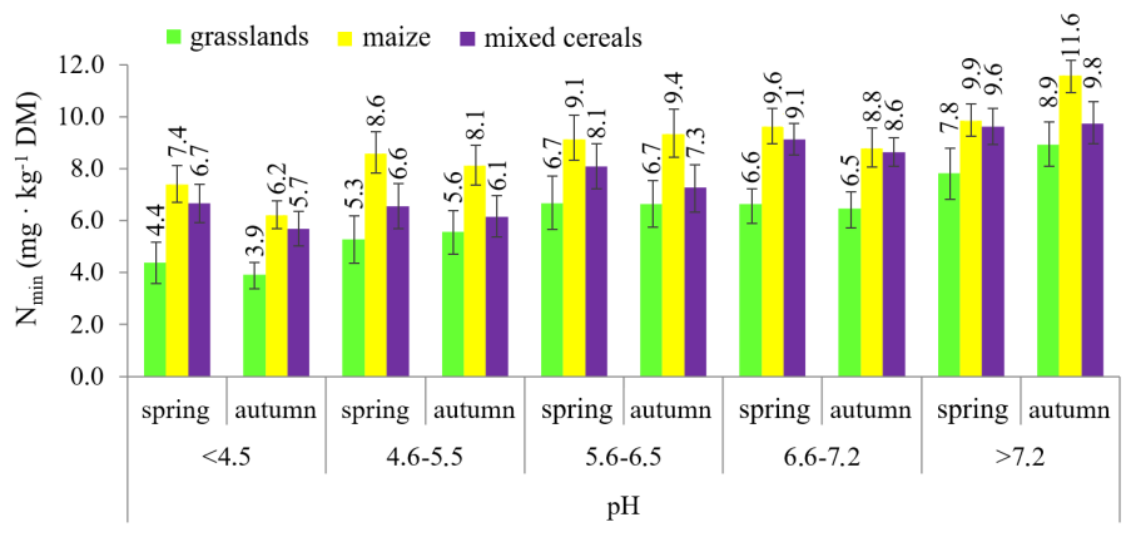

Figure 5. Average mineral nitrogen $N_{\min }$ content in the $60-90 \mathrm{~cm}$ layer of mineral soils depending on land use, sampling date, and soil pH. DM stands for dry matter of the soil sample

In organic soils, an increase in $\mathrm{N}_{\min }$ content in the $60-90 \mathrm{~cm}$ layer under grasslands was noted both in spring and in autumn, but mostly to a $\mathrm{pH}$ of 6.5. Above this value, the amount of $\mathrm{N}_{\min }$ in the evaluated layer decreased, particularly in spring (Fig. 6).

$\mathrm{N}_{\min }$ content in soils under grasslands was also modified by a higher soil $\mathrm{pH}$ and land use. This applied in particular to meadows (spring and autumn) and also pastures, predominantly at sites with a $\mathrm{pH}$ above 6.5 , as well as to hay and pasture grasslands with a $\mathrm{pH}$ above 5.5 (Fig. 7). 
On the other hand, a different situation was observed for $\mathrm{N}_{\min }$ content in organic soils - the highest content was found in soils with a slightly acidic $\mathrm{pH}$, primarily in hay and pasture grasslands as well as in pastures. At a higher $\mathrm{pH}$, the $\mathrm{N}_{\min }$ content was lower than in more strongly acidified soils (Fig. 8).

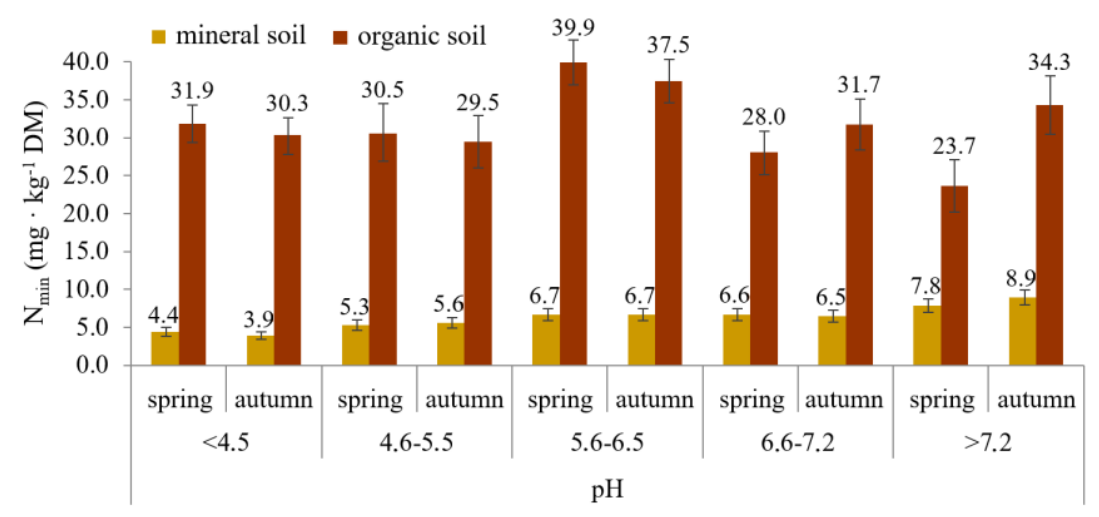

Figure 6. Average mineral nitrogen $N_{\min }$ content in the 60-90 cm layer of mineral and organic soils depending on sampling date and soil pH. DM stands for dry matter of the soil sample

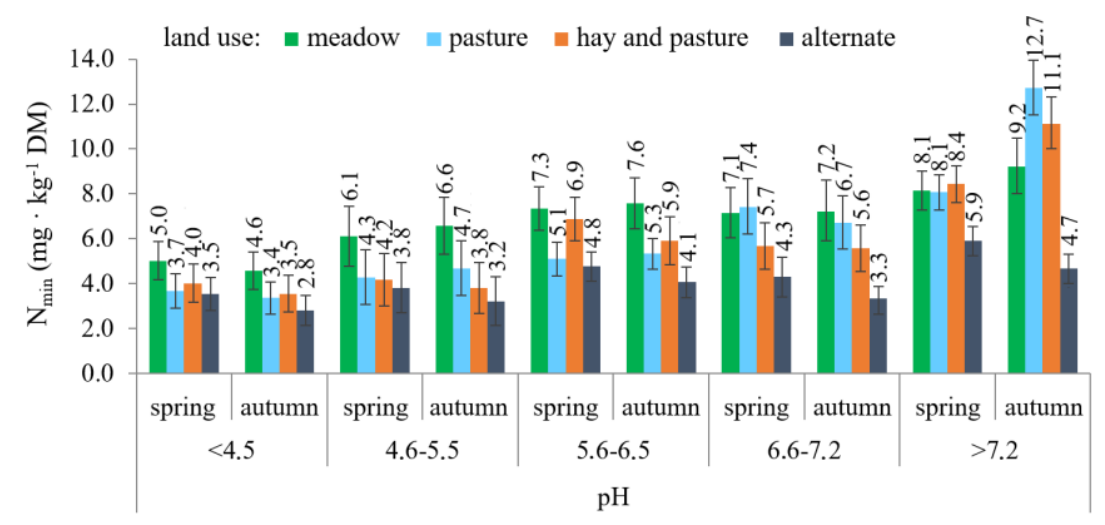

Figure 7. Average mineral nitrogen $N_{\min }$ content in the $60-90 \mathrm{~cm}$ layer of mineral soils depending on grassland land use, sampling date, and soil $\mathrm{pH}$. DM stands for dry matter of the soil sample

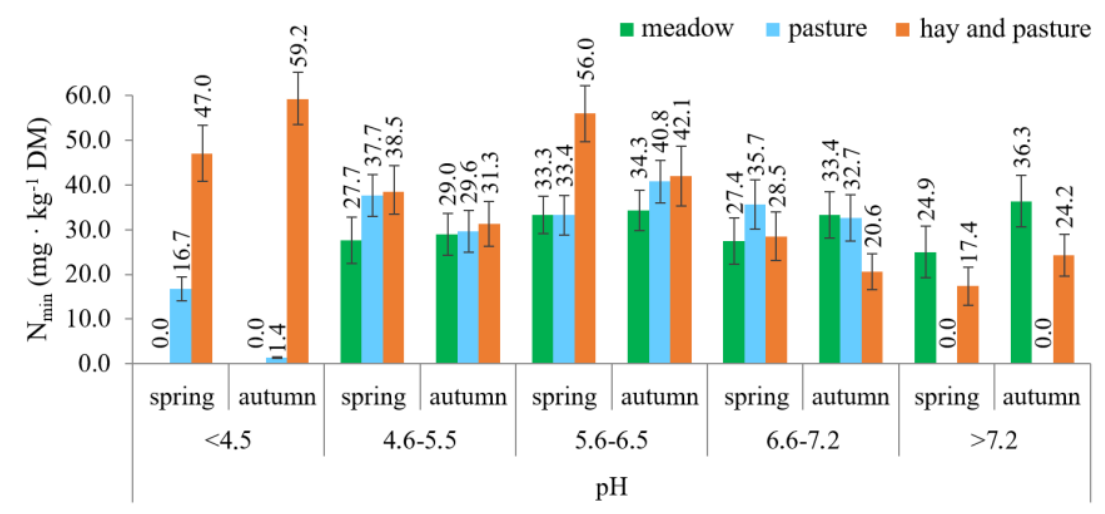

Figure 8. Average mineral nitrogen $N_{\min }$ content in the $60-90 \mathrm{~cm}$ layer of organic soils depending on grassland land use, sampling date, and soil $\mathrm{pH}$. DM stands for dry matter of the soil sample 
The obtained study results were confirmed statistically (Table 2, Figs. 9-12). A strong positive correlation was shown between soil $\mathrm{pH}$ and $\mathrm{N}_{\min }$ content in the $60-90 \mathrm{~cm}$ layer, predominantly for mineral soils, both in spring and in autumn. During the spring period, organic soils exhibited a negative relationship between soil $\mathrm{pH}$ and $\mathrm{N}_{\min }$ content, but in autumn this trend did not persist. In spring, in objects with higher $\mathrm{pH}$, a smaller amount of $\mathrm{N}_{\min }$ in the 60-90 cm layer was found for organic soils, especially on meadows and hay and pastures. It means that the $\mathrm{N}_{\min }$ losses decreased with increasing $\mathrm{pH}$. In organic soils the ammonium form predominated over nitrate form, and the lack of grazing, or partial grazing, contributed to a smaller extent to the amount of $\mathrm{N}_{\text {min }}$ coming from animal waste. Sapek (2010) observed that the release of the ammonium nitrogen $\left(\mathrm{N}-\mathrm{NH}_{4}\right)$ was significantly reduced with decrease of the soil acidity. On the other hand, the lower acidity of the soil favored the nitrification and release of nitrate nitrogen $\left(\mathrm{N}-\mathrm{NO}_{3}\right)$. Similar conclusions were drawn by Skowron (2004), who observed that the content of active forms of nitrogen $\left(\mathrm{N}-\mathrm{NH}_{4}\right.$ and $\left.\mathrm{N}-\mathrm{NO}_{3}\right)$ in the mineral soils depended highly on their $\mathrm{pH}$. Acidification clearly contributed to the increase in the content of ammonium nitrogen, while the content of nitrate nitrogen increased with increasing $\mathrm{pH}$. In these mineral soils, the nitrate form was also predominant over the ammonium form. But in organic soils this tendency is reversed. In soils under meadow land use, especially permanent grasslands, the sodding process and the way they are used, as well as fertilization, additionally shape the dynamics and course of nitrogen release from the soil.

Table 2. Relationships between soil $\mathrm{pH}$ and mineral nitrogen $N_{\min }$ content in the $60-90 \mathrm{~cm}$ soil layer expressed in terms of correlation coefficients with a breakdown into both land use and soil sampling date

\begin{tabular}{|c|c|c|}
\hline \multirow{2}{*}{ Land use } & \multicolumn{2}{|c|}{ Sampling date } \\
\hline & spring & autumn \\
\hline Grasslands on mineral soils & $0.97^{*}$ & $0.92^{*}$ \\
\hline Meadows on mineral soils & $0.95^{*}$ & $0.91^{*}$ \\
\hline Pastures on mineral soils & $0.97^{*}$ & $0.85^{*}$ \\
\hline Hay and pasture grasslands on mineral soils & $0.87^{*}$ & $0.84^{*}$ \\
\hline Alternate grasslands on mineral soils & $0.85^{*}$ & $0.80^{*}$ \\
\hline Grasslands on organic soils & $-0.48^{*}$ & $0.48^{*}$ \\
\hline Meadows on organic soils & $-0.51^{*}$ & $0.85^{*}$ \\
\hline Pastures on organic soils & $0.75^{*}$ & $0.78^{*}$ \\
\hline Hay and pasture grasslands on organic soils & $-0.72^{*}$ & $-0.83^{*}$ \\
\hline Maize & $0.98^{*}$ & $0.91^{*}$ \\
\hline Mixed cereal & $0.96^{*}$ & $0.98^{*}$ \\
\hline Total soils & $0.77^{*}$ & $0.90^{*}$ \\
\hline Total mineral soils & $0.99^{*}$ & $0.96^{*}$ \\
\hline Total organic soils & $-0.48^{*}$ & $0.48^{*}$ \\
\hline Total soils (on an annual basis) & \multirow{3}{*}{\multicolumn{2}{|c|}{$\begin{array}{c}0.85^{*} \\
0.99^{*} \\
-0.17^{*}\end{array}$}} \\
\hline Total mineral soils (on an annual basis) & & \\
\hline Total organic soils (on an annual basis) & & \\
\hline
\end{tabular}

* correlation significant at significance level $\mathrm{p}=0.05$

Additionally, the soil's abundance in organic matter can affect the efficiency of nitrogen mineralization (Sapek, 2010). As demonstrated by Hatch et al. (2002), nitrogen immobilization resulted from the increased activity of soil microorganisms. It should be emphasized that the organic carbon had contradictory influence on the nitrogen release 
to the soil solution. The increase of the $\mathrm{C}_{\text {org }}$ content promotes the binding of nitrogen in the soil and reduces the solubility of its mineral forms. Smaller amounts of nitrate nitrogen may indicate a lower intensity of the nitrification process. In the soils with smaller humus content, the mineralization process is stronger than in the soils with a high content of organic carbon. In the study of Sapek and Kalińska (2004) the amount of $\mathrm{N}$ released in the process of mineralization in acid soil was $186.6 \mathrm{~kg} \mathrm{~N} \cdot \mathrm{ha}^{-1} \cdot$ year $^{-1}$, whereas in the limed soil it was $164.1 \mathrm{~kg} \mathrm{~N} \cdot \mathrm{ha}^{-1} \cdot \mathrm{year}^{-1}$. According to the same authors, the mineralization of nitrogen is more intensive in the summer months (May - July), which increases the release of mineral forms during and after the growing season, and results in increased leaching in autumn. Mineralization, as well as leaching, are also impacted by weather conditions, especially by air temperature and precipitation.

In the case of maize and mixed cereal crops, on the other hand, the measurements made both in spring and in autumn confirmed significant positive relationships between $\mathrm{pH}$ and $\mathrm{N}_{\min }$, with the value of correlation coefficient above 0.9 . The highest negative correlation coefficients in spring and autumn were demonstrated for hay and pasture use on organic soils. The calculated coefficients of determination confirmed the significant effect of mineral soil $\mathrm{pH}$ on $\mathrm{N}_{\min }$ content, regardless of sampling date, both in grasslands and in soils under mixed cereal and maize crops. But $\mathrm{pH}$ could only slightly modify (by only 24\%) the occurrence of nitrogen in the 60-90 cm layer of organic soil.
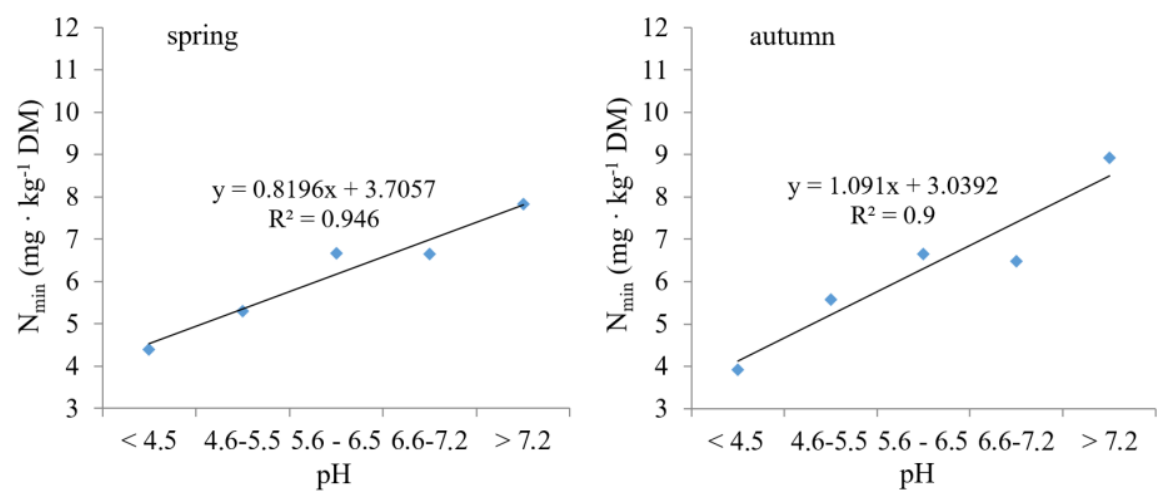

Figure 9. Relationship between soil $\mathrm{pH}$ and average mineral nitrogen $N_{\min }$ content in the 60-90 $\mathrm{cm}$ layer of mineral soils under grasslands for spring and autumn soil sampling dates. DM stands for dry matter of the soil sample
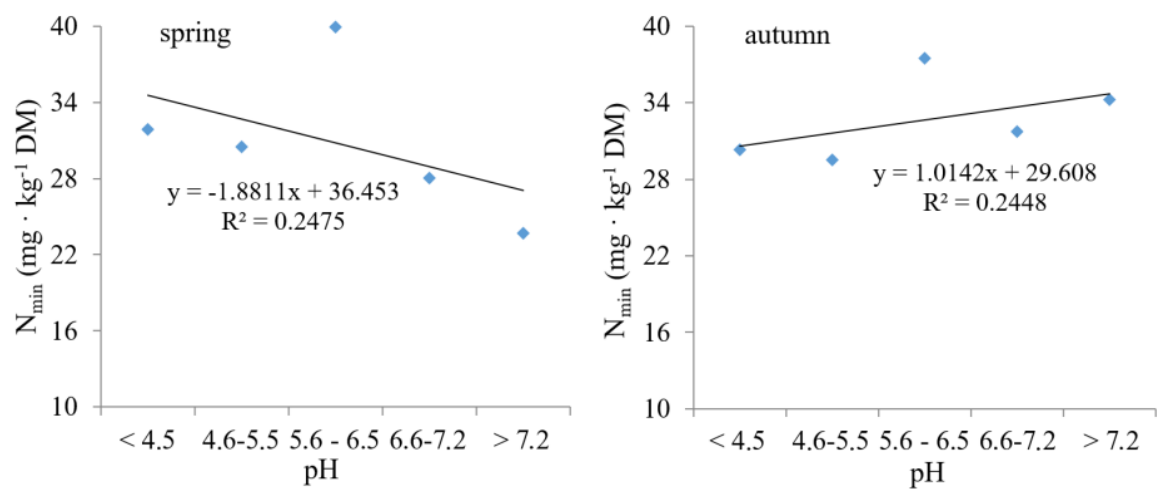

Figure 10. Relationship between soil $p H$ and average mineral nitrogen $N_{\min }$ content in the 60$90 \mathrm{~cm}$ layer of organic soils under grasslands for spring and autumn soil sampling dates. DM stands for dry matter of the soil sample 

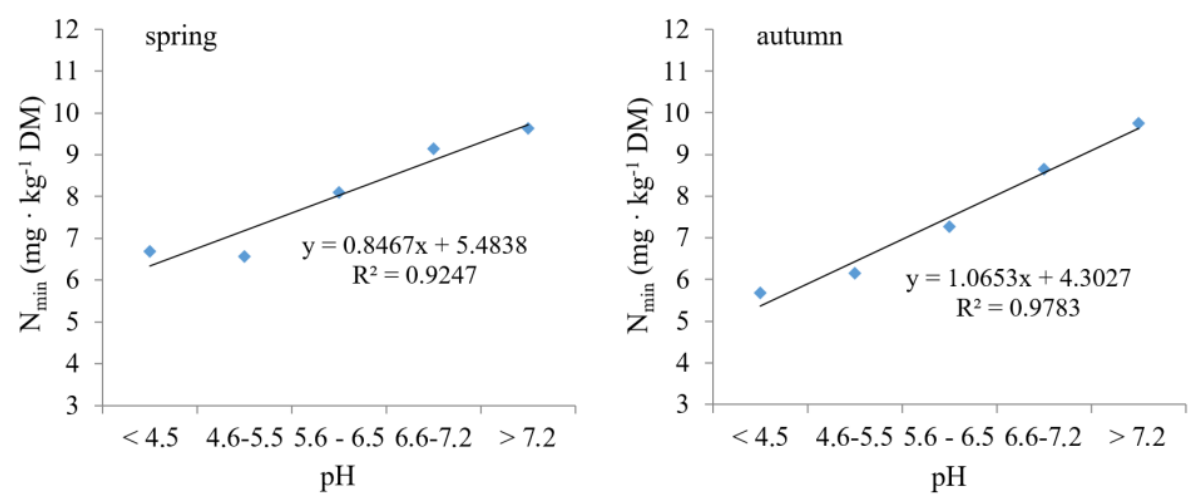

Figure 11. Relationship between soil $p H$ and average mineral nitrogen $N_{\min }$ content in the 60$90 \mathrm{~cm}$ layer of mineral soils under mixed cereals for spring and autumn soil sampling dates.

DM stands for dry matter of the soil sample
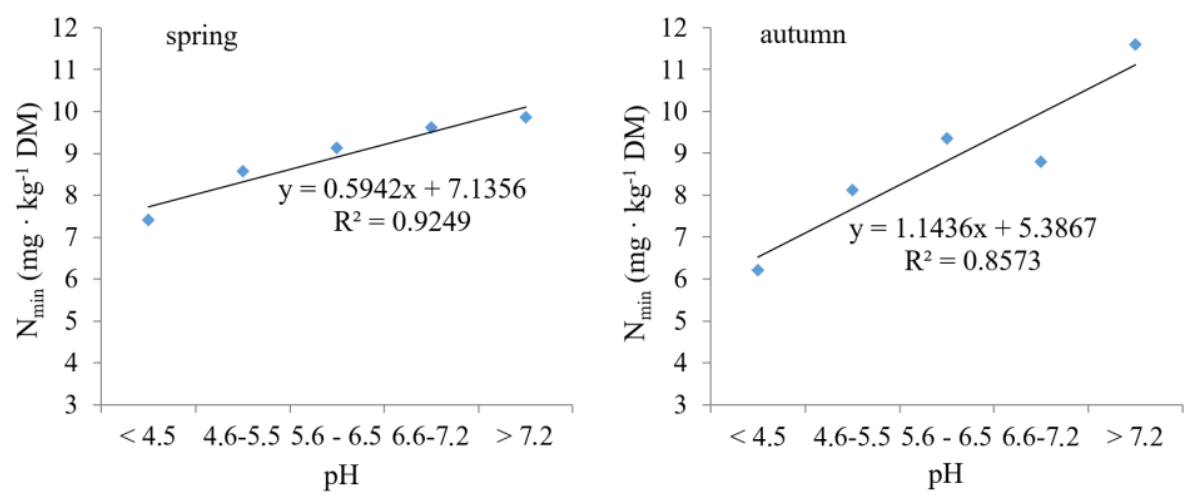

Figure 12. Relationship between soil $p H$ and average mineral nitrogen $N_{\min }$ content in the 60$90 \mathrm{~cm}$ layer of mineral soils under maize for spring and autumn soil sampling dates. DM stands for dry matter of the soil sample

\section{Conclusions}

The results of this study confirm that there is a strong relationship between $\mathrm{pH}$ of the studied soils and $\mathrm{N}_{\min }$, regardless of soil sampling date, use of the studied soils, or organic carbon content in them. In the case of samples collected in autumn, the correlation coefficient was usually positive and had a lower value than for samples collected in spring, for which, in turn, negative correlations (anticorrelations) were found more frequently. Only organic soils exhibited negative correlations, but at the same time these were one of the lowest correlation coefficients obtained. Mineral soils were characterized by a strongly positive relationship between $\mathrm{pH}$ and $\mathrm{N}_{\min }$ content. Land use did not cause significant differences in this relationship. The obtained results are extremely important from the utilitarian point of view because they can facilitate determining an optimal rate of mineral nitrogen in soils of varying $\mathrm{pH}$. This may lead to reduction of leaching of nitrogen from topsoil and its infiltration to groundwater, as well as its emissions as $\mathrm{NO}_{2}$, which is a greenhouse gas with huge contribution to creating the greenhouse effect, and ultimately, to decrease the harmful impact of grasslands and agricultural crops on environment. 
Acknowledgements. This paper has been partly financed from the funds of the Polish National Centre for Research and Development within the framework of the project BIO-FERTIL, contract number: BIOSTRATEG3/347464/5/NCBR/2017.

\section{REFERENCES}

[1] Arbačiauskas, J., Staugaitis, G., Vaišvila, Z., Mažvila, J., Adomaitis, T., Šumskis, D., Enė, L. Ž., Lubytè, J., Mažeika, R. (2014): The interdependence of mineral nitrogen content in different soil layers of Lithuanian agricultural lands. - Žemdirbystė (Agriculture) 101(2): 133-138. http://dx.doi.org/10.13080/z-a.2014.101.017.

[2] Baranowski, P., Krzyszczak, J., Sławiński, C., Hoffmann, H., Kozyra, J., Nieróbca, A., Siwek, K., Gluza, A. (2015): Multifractal analysis of meteorological time series to assess climate impacts. - Climate Research 65: 39-52. https://doi.org/10.3354/cr01321.

[3] Burton, S. A., Prosser, J. I. (2001): Autotrophic ammonia oxidation at low pH through urea hydrolysis. - Applied and Environmental Microbiology 67(7): 2952.

[4] Coyne, M. S., Frye, W. W. (2005): Nitrogen in soil. Cycle. - In: Hillel, D. (ed.) Encyclopedia of soil in the environment. Elsevier Ltd., 13-21.

[5] De Boer, W., Kowalchuk, G. A. (2001): Nitrification in acid soils: micro-organisms and mechanisms. - Soil Biology and Biochemistry 33: 853-866.

[6] Filipek, T., Skowrońska, M. (2013): Current dominant causes and effects of acidification of soils under agricultural use in Poland. - Acta Agrophysica 20(2): 283-294. (in Polish).

[7] Fotyma, M., Kęsik, K., Pietruch, C. (2010): Mineral nitrogen in soils of Poland as an indicator of plants nutrient requirements and soil water cleanness. - Nawozy i Nawożenie 38: 4-83. (in Polish).

[8] Fronzek, S., Pirttioja, N., Carter, T. R., Bindi, M., Hoffmann, H., Palosuo, T., RuizRamos, M., Tao, F., Trnka, M., Acutis, M., Asseng, S., Baranowski, P., Basso, B., Bodin, P., Buis, S., Cammarano, D., Deligios, P., Destain, M. F., Dumont, B., Ewert, F., Ferrise, R., François, L., Gaiser, T., Hlavinka, P., Jacquemin, I., Kersebaum, K. C., Kollas, C., Krzyszczak, J., Lorite, I. J., Minet, J., Minguez, M. I., Montesino, M., Moriondo, M., Müller, C., Nendel, C., Öztürk, I., Perego, A., Rodríguez, A., Ruane, A. C., Ruget, F., Sanna, M., Semenov, M. A., Sławiński, C., Stratonovitch, P., Supit, I., Waha, K., Wang, E., Wu, L., Zhao, Z., Rötter, R. P. (2018): Classifying multi-model wheat yield impact response surfaces showing sensitivity to temperature and precipitation change. Agricultural Systems 159: 209-224. https://doi.org/10.1016/j.agsy.2017.08.004.

[9] Gleń-Karolczyk, K., Boligłowa, E., Antonkiewicz, J. (2018): Organic fertilization shapes the biodiversity of fungal communities associated with potato dry rot. - Applied Soil Ecology 129: 43-51. https://doi.org/10.1016/j.apsoil.2018.04.012.

[10] Gonet, S., Smal, H., Chojnicki, J. (2015): Chemical properties of soil. - Soil science. Warszawa, PWN, 201-205. (in Polish),

[11] Grover, S. P., Butterly, C. R., Wang, X., Tang, C. (2017): The short-term effects of liming on organic carbon mineralisation in two acidic soils as affected by different rates and application depths of lime. - Biology and Fertility of Soils 53: 431-443.

[12] Hatch, D., Goulding, K., Murphy, D. (2002): Nitrogen. - Agriculture, hydrology and water quality. CABI Publishing, 7-27.

[13] Hoffmann, H., Baranowski, P., Krzyszczak, J., Zubik, M., Sławiński, C., Gaiser, T., Ewert, F. (2017): Temporal properties of spatially aggregated meteorological time series. - Agricultural and Forest Meteorology 234-235: 247-257. https://doi.org/10.1016/j.agrformet.2016.12.012.

[14] Kennedy, N., Connolly, J., Clipson, N. (2004): Impact of lime, nitrogen and plant species on bacterial community structure in grassland microcosms. - Environmental Microbiology 7: 780-788. 
[15] Krzyszczak, J., Baranowski, P., Hoffmann, H., Zubik, M., Sławiński, C. (2017a): Analysis of Climate Dynamics Across a European Transect Using a Multifractal Method. - In: Rojas, I., Pomares, H., Valenzuela, O. (eds.) Advances in Time Series Analysis and Forecasting: Selected Contributions from ITISE 2016 - Contributions to Statistics. Springer International Publishing, Cham, 103-116. https://doi.org/10.1007/978-3-31955789-2_8.

[16] Krzyszczak, J., Baranowski, P., Zubik, M., Hoffmann, H. (2017b): Temporal scale influence on multifractal properties of agro-meteorological time series. - Agricultural and Forest Meteorology 239: 223-235. https://doi.org/10.1016/j.agrformet.2017.03.015.

[17] Krzyszczak, J., Baranowski, P., Zubik, M., Kazandjiev, V., Georgieva, V., Sławiński, C., Siwek, K., Kozyra, J., Nieróbca, A. (2018): Multifractal characterization and comparison of meteorological time series from two climatic zones. - Theoretical and Applied Climatology (in press). http://dx.doi.org/10.1007/s00704-018-2705-0.

[18] Kyveryga, P. M., Blackmer, A. M., Ellsworth, J. W., Isla, R. (2004): Soil pH effects on nitrification of fall-applied anhydrous ammonia. - Soil Science Society of America Journal 68: 545-551.

[19] Lamorski, K., Pastuszka, T., Krzyszczak, J., Sławiński, C., Witkowska-Walczak, B. (2013): Soil water dynamic modeling using the physical and support vector machine methods. - Vadose Zone Journal 12(4). https://doi.org/10.2136/vzj2013.05.0085

[20] Lipiński, W. (2010): The content of mineral nitrogen in arable soils of nitrate vulnerable zones (NVZ). - Nawozy i Nawożenie 38: 111-120.

[21] Łoginow, W., Janowiak, J., Spychaj-Fabisiak, E. (1987): The variability of the total content of the individual forms of nitrogen in the soil. - Zeszyty Naukowe ATR Bydgoszcz 23: 13-24. (in Polish).

[22] Murat, M., Malinowska, I., Gos, M., Krzyszczak, J. (2018): Forecasting daily meteorological time series using ARIMA and regression models. - International Agrophysics 32(2): 253-264. https://doi.org/10.1515/intag-2017-0007.

[23] Paz, J. M., Ramos, C. (2004): Simulation of nitrate leaching for different nitrogen fertilization rates in a region of Valencia (Spain) using a GIS-GLEAMS system. Agriculture, Ecosystems \& Environment 103: 59-73.

[24] Pietrzak, S., Urbaniak, M., Sapek, B. (2006): The assessment of changes of the concentration and leaching of mineral forms of nitrogen in soil solutions. - WodaŚrodowisko-Obszary Wiejskie 6(17): 51-63. (in Polish).

[25] Pirttioja, N., Carter, T. R., Fronzek, S., Bindi, M., Hoffmann, H., Palosuo, T., RuizRamos, M., Tao, F., Trnka, M., Acutis, M., Asseng, S., Baranowski, P., Basso, B., Bodin, P., Buis, S., Cammarano, D., Deligios P., Destain, M. F., Dumont, B., Ewert, F., Ferrise, R., François, L., Gaiser, T., Hlavinka, P., Jacquemin, I., Kersebaum, K. C., Kollas, C., Krzyszczak, J., Lorite, I. J., Minet, J., Minguez, M. I., Montesino, M., Moriondo, M., Müller, C., Nendel, C., Öztürk, I., Perego, A., Rodríguez, A., Ruane, A. C., Ruget, F., Sanna, M., Semenov, M. A., Sławiński, C., Stratonovitch, P., Supit, I., Waha, K., Wang, E., Wu, L., Zhao, Z., Rötter, R. P. (2015): Temperature and precipitation effects on wheat yield across a European transect: a crop model ensemble analysis using impact response surfaces. - Climate Research 65: 87-105. https://doi.org/10.3354/cr01322.

[26] Pokojska, U. (2004): Soil reaction. - Ecological-soil investigations. Warszawa, PWN, 198-204. (in Polish).

[27] Powlson, D. S. (1988): Measuring and minimising losses of fertilizer nitrogen in arable agriculture. - In: Jenkinson, D. S., Smith, K. A. (eds.) Nitrogen Efficiency in Agricultural Soils. Elsevier Applied Science, 231-245.

[28] Regulation (2002): Regulation of the Minister of Environment of 23 December 2002 concerning specific requirements to be met by action programs aimed at reducing runoff of nitrogen from agricultural sources. - Dz. U. (Journal of Laws) of 2003, No. 4, item 44.

[29] Rodríguez, A., Ruiz-Ramos, M., Palosuo, T., Carter, T. R., Fronzek, S., Lorite, I. J., Ferrise, R., Pirttioja, N., Bindi, M., Baranowski, P., Buis, S., Cammarano, D., Chen, Y., 
Dumont, B., Ewert, F., Gaiser, T., Hlavinka, P., Hoffmann, H., Höhn, J. G., Jurecka, F., Kersebaum, K. C., Krzyszczak, J., Lana, M., Mechiche-Alami, A., Minet, J., Montesino, M., Nendel, C., Porter, J. R., Ruget, F., Semenov, M. A., Steinmetz, Z., Stratonovitch, P., Supit, I., Tao, F., Trnka, M., de Wit, A., Rötter, R. P. (2019): Implications of crop model ensemble size and composition for estimates of adaptation effects and agreement of recommendations. - Agricultural and Forest Meteorology 264: 351-362. https://doi.org/10.1016/j.agrformet.2018.09.018.

[30] Rousk, J., Bååth, E., Brookes, P. C., Lauber, C. L., Lozupone, C., Caporaso, J. G., Knight, R., Fierer, N. (2010): Soil bacterial and fungal communities across a pH gradient in an arable soil. - ISME Journal 4: 1340-1351. http://dx.doi.org/10.1038/ismej.2010.58.

[31] Ruiz-Ramos, M., Ferrise, R., Rodríguez, A., Lorite, I. J., Bindi, M., Carter, T. R., Fronzek, S., Palosuo, T., Pirttioja, N., Baranowski, P., Buis, S., Cammarano, D., Chen, Y., Dumont, B., Ewert, F., Gaiser, T., Hlavinka, P., Hoffmann, H., Höhn, J. G., Jurecka, F., Kersebaum, K. C., Krzyszczak, J., Lana, M., Mechiche-Alami, A., Minet, J., Montesino, M., Nendel, C., Porter, J. R., Ruget, F., Semenov, M. A., Steinmetz, Z., Stratonovitch, P., Supit, I., Tao, F., Trnka, M., de Wit, A., Rötter, R. P. (2018): Adaptation response surfaces for managing wheat under perturbed climate and $\mathrm{CO}_{2}$ in a Mediterranean environment. - Agricultural Systems 159: 260-274. https://doi.org/10.1016/j.agsy.2017.01.009.

[32] Sapek, B. (1999): Estimation of nitrogen compounds mineralization by the in situ incubation method and the nitrogen balance in the mineral meadow soil. - Wiadomości IMUZ 20(1): 39-57. (in Polish).

[33] Sapek, B. (2010): Nitrogen and phosphorus release from soil organic matter. - WodaŚrodowisko-Obszary Wiejskie 10, 3(31): 229-256. (in Polish).

[34] Sapek, B., Kalińska, D. (2004): Mineralization of soil organic nitrogen compounds in the light of long-term grassland experiments in IMUZ. - Woda-Środowisko-Obszary Wiejskie 4, 1(10): 183-200. (in Polish).

[35] Sapek, B., Kalińska, D. (2007): Mineralization of nitrogen and phosphorus compounds in the soil of agriculturally used and not used meadow. - Roczniki Gleboznawcze 58(1): 109-120. (in Polish).

[36] Siebielec, G., Smreczak, B., Klimkowicz-Pawlas, A., Maliszewska-Kordybach, B., Terelak, H., Koza, P., Hryńczuk, B., Łysiak, M., Miturski, T., Gałązka, R., Suszek, B. (2012): Monitoring of chemistry in arable soils in Poland in the years 2010-2012. IUNG-PIB w Puławach: 1-202. (in Polish).

[37] Skowron, P. (2004): Nitrogen active forms content at differentiated pH soils in laboratory experiment conditions. - Annales UMCS sec. E 59(1): 363-368. (in Polish).

[38] Soon, Y. K., Clayton, G. W., Rice, W. A. (2001): Tillage and previous crop effects on dynamics of nitrogen in a wheat-soil system. - Agronomy Journal 93: 842-849.

[39] Tkaczyk, P., Bednarek, W. (2011): Evaluation of soil reaction $(\mathrm{pH})$ in the Lublin region. - Acta Agrophysica 192(18): 173-186. (in Polish).

[40] Tkaczyk, P., Bednarek, W., Dresler, S., Krzyszczak, J., Baranowski, P., Sławiński, C. (2017): Relationship between assimilable-nutrient content and physicochemical properties of topsoil. - International Agrophysics 31(4): 551-562. https://doi.org/10.1515/intag-2016-0074.

[41] Tkaczyk, P., Bednarek, W., Dresler, S., Krzyszczak, J. (2018a): The effect of some soil physicochemical properties and nitrogen fertilisation on winter wheat yield. - Acta Agrophysica 25(1): 107-116. https://doi.org/10.31545/aagr0009.

[42] Tkaczyk, P., Bednarek, W., Dresler, S., Krzyszczak, J., Baranowski, P., Brodowska, M. S. (2018b): Content of certain macro and microelements in orchard soils in relation to agronomic categories and reaction of these soils. - Journal of Elementology 23(4): 13611372. https://doi.org/10.5601/jelem.2018.23.1.1639.

[43] Trehan, S. P. (1996): Immobilisation of ${ }^{15} \mathrm{NH}^{4+}$ in three soils by chemical and biological processes. - Soil Biology and Biochemistry 28(8): 1021-1027. 
[44] Tremblay, N., Scharpf, H. C., Weier, U., Laurence, H., Owen, J. (2001): Nitrogen management in field vegetables. A guide to efficient fertilisation. - Agriculture and AgriFood Canada, 1-63.

[45] Walczak, R. T., Witkowska-Walczak, B., Baranowski, P. (1997): Soil structure parameters in models of crop growth and yield prediction. Physical submodels. International Agrophysics 11: 111-127.

[46] Walkiewicz, A., Brzezińska, M., Bieganowski, A. (2018): Methanotrophs are favored under hypoxia in ammonium-fertilized soils. - Biology and Fertility of Soils 54(7): 861870. https://doi.org/10.1007/s00374-018-1302-9.

[47] Wnuk, E., Walkiewicz, A., Bieganowski, A. (2017): Methane oxidation in leadcontaminated mineral soils under different moisture levels. - Environmental Science and Pollution Research 24(8-9): 1-9. https://doi.org/10.1007/s11356-017-0195-8.

[48] Wong, M. T. F., Nortcliff, S. (1995): Seasonal fluctuations of native available N and soil management implications. $\quad-\quad$ Fertilizers Research 42: 13-26. https://doi.org/10.1007/BF00750496.

[49] Yu, Z., Kraus, T. E. C., Dahlgren, R. A., Horwath, W. R., Zasoski, R. J. (2003): Mineral and dissolved organic nitrogen dynamics along a soil acidity-fertility gradient. - Soil Science Society of America Journal 67: 878-888. 